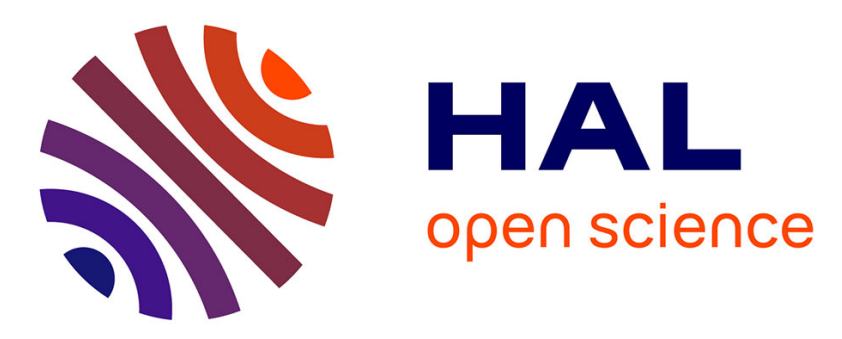

\title{
Design of an automated fixed bed reactor used for a catalytic wet oxidation process
}

Alexis El Khoury, Bouchra Bejjany, Marie Debacq, Alain Delacroix

\section{To cite this version:}

Alexis El Khoury, Bouchra Bejjany, Marie Debacq, Alain Delacroix. Design of an automated fixed bed reactor used for a catalytic wet oxidation process. ICINCO 2007 - 4th International Conference on Informatics in Control, Automation and Robotics, May 2007, Angers, France. , Proceedings of the 3rd International Workshop on Artificial Neural Networks and Intelligent Information Processing. hal-01487150

\section{HAL Id: hal-01487150 https://hal.science/hal-01487150}

Submitted on 14 Apr 2017

HAL is a multi-disciplinary open access archive for the deposit and dissemination of scientific research documents, whether they are published or not. The documents may come from teaching and research institutions in France or abroad, or from public or private research centers.
L'archive ouverte pluridisciplinaire HAL, est destinée au dépôt et à la diffusion de documents scientifiques de niveau recherche, publiés ou non, émanant des établissements d'enseignement et de recherche français ou étrangers, des laboratoires publics ou privés.

\section{(ㅇ)(1) $\$$}

Distributed under a Creative Commons Attribution - NonCommercial - NoDerivatives| 4.0 
